ISSN 1112-9867

http://www.jfas.info

\title{
THE INFLUENCE OF CORE COMPETENCY SKILLS OF IRBM TAX AUDITORS TOWARDS THEIR PERFORMANCE
}

\author{
A. H. Nadiah*, A. M. Siti Hajar, and A. R. Zarinah \\ Faculty of Accountancy, Universiti Teknologi MARA, 40450 Shah Alam, Malaysia
}

Published online: 17 October 2017

\begin{abstract}
In the current audit markets, there is much attention given to the tax auditors' role in ensuring tax compliance as the tax audit is currently the IRBM's primary activity. This study using questionnaires to examine the relationship between core competencies towards their performance in completing audit cases. The increase in tax auditor's performance may reduce the number of unresolved audit cases and increase the voluntary compliance among the taxpayers. 231 questionnaires were completed and returned to be further analysed. It takes a competent tax auditor to resolve all the audit cases and reduce the issues of dissatisfaction among taxpayers on the attitude and performance of the tax auditors. It is the responsibility of the tax administrator to improve the efficiency of tax audits by enhancing the competency of tax auditors. The result in this study shows a positive relationship between skills and knowledge towards performance.
\end{abstract}

Keywords: core competency skills; IRBM tax auditor; performance; knowledge.

Author Correspondence, e-mail: nadiah201@salam.uitm.edu.my

doi: http://dx.doi.org/10.4314/jfas.v9i5s.68 


\section{INTRODUCTION}

Tax audit has become a primary activity for Inland Revenue Board of Malaysia (IRBM) since self-assessment system and its aim is to encourage taxpayers towards voluntarily reporting the true tax computation in accordance with the tax laws. Prior to self-assessment system (SAS), IRBM was required to determine the amount of a taxpayer's liability. However, the former tax system is quite intricate due to every tax return received need to be examined and the amount of taxpayer's liability will be determined by the assessors [28]. Furthermore, the system requires both the mathematical computation of the tax (known as 'assessment') and the scrutiny of the accuracy (known as 'audit') of a taxpayer's declaration and other documents, especially the business accounts of self-employed taxpayers and these process need to be performed simultaneously [55]. Thus, the IRBM officers need to work extra hours to complete the cases, especially in the event of more complicated cases. In some cases, the process of tax assessment was extended until the following year of assessment after the issuance notice of assessment by the board resulted to delay in the collection of tax revenue for the government [83]. Thus, with SAS, the government believed that it might be able to resolve the issue of uncompleted cases of the taxpayers' returns.

However, from the statistics of the Tax Operation Department in IRBM, it showed that with $\mathrm{SAS}$, the issue of non-compliance among the taxpayers remains unresolved although the number of IRBM tax auditors kept increasing overtime. For example, for the year 2009, out of 15,813 cases audited only 8,119 were resolved. Furthermore, from the unpublished data of Tax Audit Department IRBM, it was revealed that for the period from 2009 until 2014, about $32 \%$ (for company) and 22\% (non-company) of desk audit cases were unresolved. Meanwhile for field audit, the data showed that about 35\% (company) and 51\% (non-company) respectively were unresolved cases. Previous studies found that, many factors contributing towards non-compliance issue such as complexity of the tax laws and regulation, incomplete accounting and business records kept by the taxpayers, the complexity of the tax system, the behavior of the taxpayers, inadequate financial records and a lack of knowledge among the tax payers [1] [64] [31]. One of the factors contributing towards the higher unresolved tax audit cases could be due to the lack of competence of IRBM tax auditors [2]. 


\section{PROBLEM STATEMENT}

Voluntary compliance is the assumption that taxpayers will comply with the tax laws and report their income amount accurately and make the deductions fairly and honestly. Tax penalties charged to the audited companies can also be measured as one of the indicators to identify tax compliance. Statistics provided by the IRBM in the annual report for the years 2009 to 2014 are shown in Fig. 1 and Fig. 2. From the figures it can be seen that the number of audits and the penalties had fluctuated over the years [36] [37] [38] [39] [40] [41]. In 2013, the graph shows a reduction in the number of audits resolved with high penalties issued. The audits resolved further increased in 2014 but penalties decreased slightly from the previous year by $11 \%$. Figure 1 however, shows an increasing trend of audit cases resolved from the years 2013 to 2014. Meanwhile Figure 2 shows a reduction in penalties charged for years 2013 to 2014 from the audit cases resolved [41]. However, it is not accurate to rely solely on the statistics of resolved audit issues for the year (as reported in annual report) to judge the efficiency of the tax audit performed. Hence, the internal statistics from the Tax Operation Department are also needed to evaluate the the performance of the tax audits.

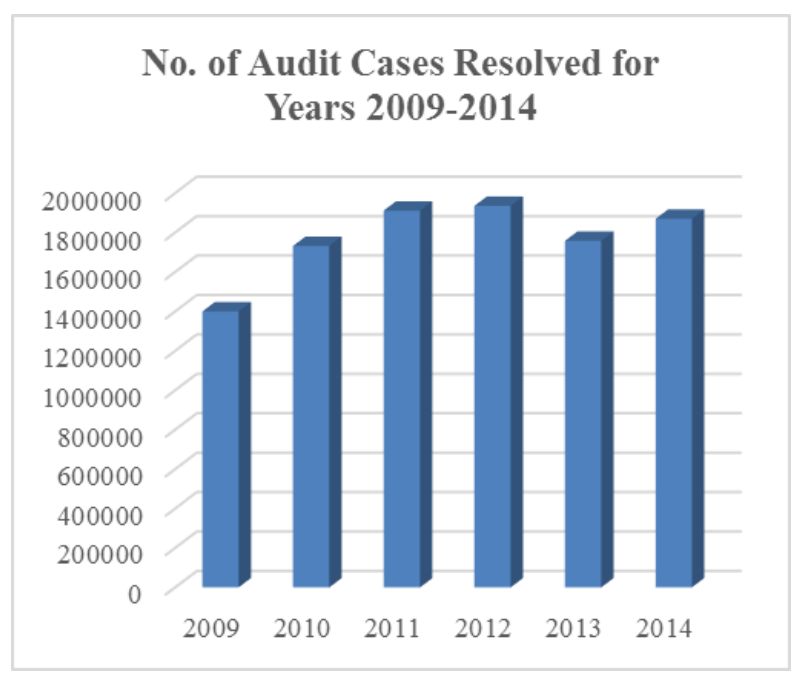

Fig.1. Tax audit settlement performance from 2009 to 2014 


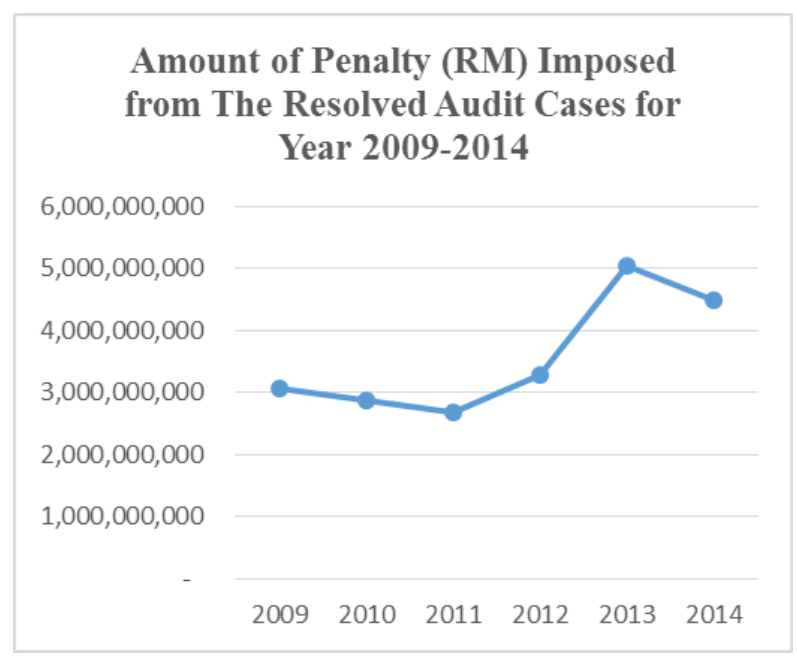

Fig.2. Penalty imposed to unresolved cases from 2009 to 2014

Performance of tax audits and the efficiency of the tax auditors can also be measured based on the number of tax audits received and resolved for the year. IRBM's Annual Report 2010 showed several selected audit cases could not be resolved. For example, for the year 2009, out of 15,813 cases audited only 8,119 were resolved [37]. This was also supported with the statistics of sample data received from the Tax Operation Department in IRBM which showed that almost a majority of the cases received every year by the Audit Unit were not resolved within the receiving year.

The average percentage of unresolved audit cases for five (5) years by the Audit Unit (based on sample selected) were; desk audit (company) 32\% and for desk audit (other than company) was $22 \%$. Meanwhile, field audit (company) is $35 \%$ and field audit (other than company) is $51 \%$. The data analysis was based on a sample of ten (10) business codes from the years 2009 to 2014 consisting of the following industries; namely the logging industry, extract crude petroleum oil, manufacturing, property, civil and food industry. These statistics suggests that often most of the auditors were not able to complete the cases given within the stipulated period and this issue may bring up queries on the competency of the IRBM tax auditors and advocates that the current practice of tax audit is not sufficient to resolve audit cases and issues on tax administration [88]. Tax auditors play a critical role towards the effectiveness of tax audits and they ensure the success of the tax audit objectives.

However, from the statistics it can be seen that the tax compliance issue remains unresolved 
although the number of IRBM tax auditors kept increasing overtime. One of the main factors could be due to the lack of competent IRBM tax auditors [2]. Thus, the aim to audit all taxpayers will not be achieved and this will affect the tax collection for the country negatively [89]. Therefore, the issue on the tax auditors' efficiency is crucial and the introduction of a new tax should be the last alternative as a new tax is associated with a loss of individual freedom to dispose of one's own money the way one wishes [86] and thus will create resistance from the citizens and consequently affect the popularity of that particular government [50]. Other researchers such as [17] [22] [42] [65] and [28] have focused on the issues of tax audit, tax evasion, perception of tax payers towards tax audit and tax auditors. However, as at to date, researchers did not find any specific study focusing on the IRBM tax auditors' performance, along with their efficiency and competency although the tax auditors plays a critical role in educating the tax payers of voluntary compliance. This is a surprising fact what with the tax audit being the primary activity in IRBM nowadays.

Previous researches by [1] [28] [31] [64] found that factors which contributed to non-tax compliance were complexity of the tax laws and regulation, incomplete accounting and business records kept by the taxpayers, the complexity of the tax system, the behaviour of the taxpayers, inadequate financial records and a lack of knowledge among the tax payers. Due to these factors, competent IRBM tax auditors are required to tackle the obstacles in conducting tax audits during fieldwork. Apart from that, research by [22] [42] found that the taxpayers were dissatisfied with the performance of the tax auditors. The taxpayers perceived that IRBM tax auditors came to their premises with biased thoughts that the taxpayer is guilty and they always create a stressful environment for the tax payer when carrying out audit fieldwork. The tax auditors also portrayed bad attitude such as being rude to the taxpayers and also raised their voice during audit fieldwork. Furthermore, it seems that the tax auditors being goal oriented and very result based in conducting their job. They were more focused on finding offences and irregularities during audit fieldwork rather than educating the tax payers on tax compliance. The reason for this could be because such target achievement is clearly stated in their key performance indicator.

The taxpayers also perceived that the tax auditors were incompetent and lacked knowledge of accounting and business which has become the root cause for the frequent delay in finalizing 
audit findings (more than 2 weeks). Such perceptions are also supported by [42] who found that more than $30 \%$ of tax auditors provided inconsistent comments and were non- compliant to tax regulations due to a lack of knowledge. [22] also added, apart from lack of knowledge, language barrier also one of the factors which contributed to the long duration taken by the tax auditors to finalize audit cases. Many taxpayers were not able to comprehend the auditor's questions due to the complicated technical terms of the tax laws used by the tax auditors to communicate with them during the audit fieldwork. If such miscommunication is prolonged, it may create difficulty to obtain taxpayers' co-operation and will definitely lengthen the audit duration and incur additional costs. Moreover, most of the time the tax auditors seem to generalize the modus operandi of the business transactions in the same nature of business or industry although at times the modus operandi differ from one company to another. As a result of such generalization, the tax auditors did not agree with the justifications given by the taxpayers and made the tax adjustments based on their judgment. However, such tax adjustments should not be carried out unless there is clear evidence that the taxpayer wilfully tried to evade tax, only then the additional tax can be charged. Based on the findings, the tax auditors usually overlook this issue and sometimes fail to provide justification on the tax adjustment and required additional tax payment upfront. Lack of cooperation from the tax payer in providing documents and information is one of the main obstacles faced by the tax auditors; hence, it is crucial for an auditor to be competent enough to handle audit cases efficiently and furnish himself with technical knowledge, audit skills and have analytical thinking [59].

The effectiveness of an audit cannot be measured by single measure for every aspect but requires numerous indicators combining the outputs and outcomes. These indicators often relate to the structures within which audit work and other compliance are undertaken. In all systems uncovering the causal chains that link a specific activity to a final effect is difficult. It is particularly hard to determine whether compliance has improved due to audit activity or some other causal influences. [4] suggested that an auditor must be a competent and independent individual as auditing involves the collection and assessment of evidence to support the findings in order to make a judgement and report on the degree of correspondence between the information and certain established criteria [5]. Therefore, the tax auditors' 
competency, their wide experience in the field and being knowledgeable of tax laws as well as the business or industry is vital to ensure the quality of the audit findings. Having strong 'soft skills' such as analytical thinking, innovative skills and negotiation skills is also one of the critical factors to be a good auditor. A good auditor should also have a proper plan prior to audit checking [4] in order to handle the audit cases efficiently.

According to Inland Revenue Department Staff Training Procedure 1982, Inland Revenue Department IRBM takes at least 18 months to two years to train newly recruited staff before they become productive employees [87]. Therefore, for IRBM to have a quality and competent tax auditors it takes more than two years for the tax auditors to master the tax laws and experience handling different audit cases. Currently the auditor is not permanently posted as a tax auditor; the position of the tax auditors can be changed anytime and they can also be transferred to other department. In addition, at present IRBM is hiring tax auditors on a contract basis so there are always new staff to do auditing. The post of tax auditor also consists of those from various backgrounds and not just those from accounting background. Therefore, an audit officer may need some time to learn and understand the accounting terminology and accounting treatment in order to start auditing.

Professionalism, integrity as well as credibility can be maintained once auditors uphold their responsibilities and ethics as an auditor and it will also enhance the audit efficiency as it is the primary principle of good governance [56] [61]. In addition, [20] and [12] suggested that audit performance can be achieved once an auditor has been furnished with adequate knowledge, have professional skills, expertise, ethics, proper education and work experience. Audit performance can be defined as the results of an audit report is in accordance to 'professional standards, accurate and proper, and appropriate time and resources are used to determine whether implementation increase or decreases [10] [52]. It also involves the effectiveness and efficiency of the audit work [35]. An audit task is considered to be undertaken in an effective manner when the auditors are able to complete the audit tasks on time and the outcome is accurate with sufficient and appropriate evidence or supporting documents to justify the findings.

The tax auditor's attitude is also one of the critical factors that influence the corporate taxpayers' compliance behaviour, especially on the approaches used by the tax auditor to 
interact with taxpayers during audit fieldwork. The rule of thumb is to treat people the way you want to be treated. Tax auditors should have adequate soft skills and appropriate behaviour which will encourage the taxpayers to voluntarily comply with the tax regulations in the future. According to [42], if the tax auditors treated the taxpayers with respect and use physiological approach during the audit process, this will build trust among the taxpayers towards the tax auditors which will then have a positive impact on voluntary compliance among the taxpayers. [11] [27] [47] supported such findings; their research discovered that taxpayers feel helpless on the arbitrary audit procedures which then demotivate them to comply. However, if there was fair administration of tax audit, the taxpayers will be inclined to be more tax compliant. In order to improve tax auditors' communication, technical knowledge, and audit skills. [59] study suggested that continuous training is essential. Although trainings have been carried out by IRBM to all staff, the preliminary survey revealed that all the officers had attended technical courses to strengthen their knowledge and understanding of tax laws but only a few of them were given an opportunity to attend soft skill courses such as negotiation skills course which is essential for a tax auditors to perform audit task efficiently.

\section{LITERATURE REVIEW}

\subsection{Tax Auditor's Performance}

Audit performance can be defined as the result of the audit report is in accordance with the professional standards, which are accurate, proper, timely and resourceful [10] [47]. It is supported by [26] who found that insufficient time is always the obstacle of an auditor to achieve the desired results. Audit performance is able to create a reputation for an auditor and good reputation assisted the firm building image in the industry such as, successfully preparing reports on time [63]. A higher audit performance leads to a higher continuous reputation [54] and ensures the continuity of the auditor's profession. Audit capability is also known as audit responsibility competency which is being able to contribute towards persistently performed audit tasks.

Balance scorecard approach was used to measure the tax audit performance [6]. The indication of audit performance is based on the result of the real audit work which is reflected 
from the tax auditors' competency. The level of competency will enable the auditor to find irregularities and non-compliance to tax regulation. According to [32] it is indicated that the regulatory and professional bodies involved in image creation and support of audit quality have tried to improve bad image and increase legitimacy. On top of that, the quality of tax audit was also evaluated by the tax audit unit supervisor and top management, however, it is subjective and could hardly be measured [6]. Thus, auditors should have the knowledge, skills, and other abilities to conduct their individual responsibility to perform the audit and ensure the reliability of opinion on the report meets reality. There were several approaches used to monitor the performance of the tax auditors to ensure the expectation of the unit and the organization as a whole which have been achieved and the performance was satisfactory such as conducting meetings and discussion. Besides this, the number of cases work, casework quality and the target collection amount are also one of the evaluation criteria [6].

\subsection{Tax Auditor's Competency}

Competence can be defined as the capabilities of an individual to perform his tasks and roles as expected. It is actually a 'set of defined behaviour's as an outline to assist employers to identify, evaluate and develop an individual behaviour. The term capability represent specific skills, knowledge and attributes that are required of the staff to perform a specific job in a competent (i.e. efficient and effective) manner which can continuously improve through training, exams, and education [80]. Whereas, in the accounting context, International Federation of Accountants (IFAC) Education Committee (2006) defined competency as the ability of a person to perform roles and duties expected as a professional accountant, both newly qualified and experienced, to the standard expected by employers and the general public". Examining an auditor's competency is fundamental to create success [34]. [3] divided competencies into three sections: 'functional competencies', 'personal competencies', and 'broad business perspective competencies'. The competency of an auditor can be measured based on two (2) factors; demographic factors [26] and core competency factors [44].

\subsubsection{Core Competencies and Tax Audit Performance}

Core competence can be defined as a unique combination of successful factors which consists of human skills, knowledge, process, products and value chain or technology that provide 
value to users and ensure the continuous competitive advantage in achieving the goals and objectives [68]. There are three (3) main competencies; communication skills including the 'presentation', 'oral' and 'report writing', recognizing problem and solution such as conceptual and analytical thinking, always update with the revision of current laws and regulation and also industry. Besides audit tools and techniques, knowledge is also significant. [9] suggested that the business understanding is the most crucial element under technical skills in assisting the auditors to effectively carry out the auditing job as they are able to recognize the risk and the control issues.

It is actually difficult to measure the competency and capabilities in a real life setting, as the actual performance can only be recognised whenever the audit fails. There are a few potential threats; inadequate knowledge and expertise in the related field, traps on judgement and biasness, pressure to meet deadlines, inherited expectations and preferences, the character of an auditor, culture and attributes, performance appraisal [23]. In addition, other potential threats include conflict of interest in auditing clients, limited resources, ineffective utilization of specialists and experts and client characteristics. Theoretically, in a tax audit context, the competency of tax auditors is measured through the completion of the final assessment during compulsory tax training attended by the tax officers, who are well versed in tax laws and regulations, are able to recognize relevant standards, comprehend and familiar with the related framework or guideline and applicable reporting requirement as well as execute relevant audit procedures. It is crucial for an auditor to perform in auditing and enhance their competency through continuously training and performing audits [90]. Tax auditors maintain their competency through updating knowledge on any revision of tax laws and regulation, continuous training, such as technical tax subject each year, refreshment training, obtain advanced certification or specialized knowledge. The designed education program was aimed to develop and attract talent in building a high quality staff and sustain the professional competency among tax payers and ensure they comply with professional standards plus applicable legal and regulatory requirements. However, the actual audit achievement is evaluated to measure the competency.

Core competency is significant to improve their proficiency and the effectiveness and quality of their services. It can be improved through professional education and development process 
on competency. To be successful professional auditors, certain competencies are required. Based on CFIA research conducted by [91] for the result of internal auditing profession from 1996 to 1999, found that knowledge and skills identified as important criteria's for entry level of auditors were: 'general business knowledge', 'communication skills', 'accounting knowledge', 'interpersonal skills and personal behaviour', 'problem-solving skills', 'computer skills' and 'knowledge on information technology' and 'personal capabilities' [68].

A successful auditor should have certain criteria's and there are seven (7) basic audit principles introduced by an auditor in performing tasks, as suggested by the [66] which are; objectivity, independency, responsibility and accountability, capability, confidentiality, objectivity and cooperation. Sense of responsibility actually drives the auditor to perform their task with integrity, competency and honesty. In addition to that, the main components in competency profile listed by the IRBM are the knowledge, skills and attitudes of officers. These components are divided into three (3) sub categories; Individual Abilities, Teamwork and Organisational Commitment and Customer Focus. The subcategories consist of 19 competencies as detailed out in Table 1 . The profile was created as a guideline and references to the human resources department in conducting human resource activities such as recruitment, career path, and succession planning, training management and performance management. However, assessment specifically on tax auditors' was not revealed.

Table 1. IRBM competency profile

\begin{tabular}{|l|l|l|l|}
\hline No. & Individual Abilities & Teamwork & $\begin{array}{l}\text { Organisational Commitment } \\
\text { and Customer Focus }\end{array}$ \\
\hline 1. & Self Control & Cooperation & Communication Skills \\
\hline 2. & Self Confidence & Leadership & Organizational Commitment \\
\hline 3. & Initiative & Persuasiveness & Customer Service Orientation \\
\hline 4. & Work Quality & $\begin{array}{l}\text { Ability to Develop } \\
\text { officers }\end{array}$ & Interpersonal Skills \\
\hline 5. & Result Orientation & Decision making & Resourcefulness \\
\hline 6. & Flexibility & - & - \\
\hline 7. & Analytical Thinking & - & - \\
\hline 8. & Functional Expertise & - & - \\
\hline
\end{tabular}


On top of that, core competency factor is listed based on actual key performance indicator of the tax auditors. There are nine factors to be achieved by an auditor such as; skills, knowledge, innovation, sustainability, quality, commitment, achievement orientation, team work and independence [40]. The detail hypothesis development of the factors is detailed out in the next section.

\subsubsection{Innovation}

The term innovation means developing, introducing or applying new ideas where the adoption will benefit others or result in a more effective and efficient process [85] and is an added value to the auditor [9] [21] delineating the "stages of maturation paths" [72]. It is suggested that an innovative mind have significant relationship with job performance and critical thinking can also be considered as innovative because they will be able to evaluate ideas and information in different or out of normal perspective. Critical thinking was defined as reviewing ideas that has been produced and reaching tentative decisions on the most reasonable belief about any issues and further refining solution or belief [76], in improving audit work.

Many studies such as [48] [62] [77] supported the significance of being innovative in resulting better job performance. The innovative behaviour has positive relationship with knowledge which encourages employees to think about problems in new ways and challenge their beliefs and inspires them to go above and beyond every day expectations. However, [45] found insignificant findings between creative climate and the behavior on performance although the findings are expected to be significant based on other research. These insignificant findings may be due to the reduced variety of samples or due to range restriction. The above discussion leads to the formulation of the following hypothesis: H1: Innovative behaviour is positively related with tax audit performance

\subsubsection{Sustainability}

Sustainability in this context is the survival of an auditor. In this study, sustainability is defined as the continuity of an auditor to be competent in the auditing field and create audit reputation [16] [45]. The structures of the audit industry nowadays are the outcome of the processes of successful auditors and survival in the profession. Furthermore, audit survival depend on the legitimacy resulting from the efficacy of audit and auditors who have been 
entrusted to continuously audit customers, and constantly doing auditing [57]. Previous studies emphasize that it is required for auditors to uphold the rigorous regulation, morals, and ethics within the audit industry in ensuring the survival of the auditors' profession survival. Thus, to achieve audit survival, auditors must continuously conduct these activities and bring trust towards their audit practice. Besides that, maintaining the quality of audit is important to preserve and develop the positive audit image towards the audit profession [82]. Research by [84] found significant findings on the sustainability towards tax auditor's performance. This is supported by [7] who found that staff will improve themselves in performing their work in order to be sustained in their departments or firms. The above discussion leads to the formulation of the following hypothesis:

H2: Sense of sustainability is positively influence the tax auditor's performance.

\subsubsection{Audit Quality}

Audit quality is subjective to be measured; it consists of qualitative and quantitative measures. Audit quality is interrelated with the auditors' judgement on the quality of their judgments. According to [5] audit quality is effective detection process on material misstatement. It is the reflection of the auditor's competence, while reporting is a reflection of ethics or audit integrity, independence An organization can influence or control many aspects of its internal processes that enable improvements in the quality of auditor judgments and audit quality. This effort has potential to enhance the effectiveness of monitoring audit quality and audit methodologies by capturing engagement level data in a manner that would allow analysis of audit characteristics and results. The overall impression is known as audit image which is perceived in the minds of people who trust specialized examination, control of the performance, a code of ethics, and the responsibility sense of the auditor [25].The above discussion lead to the formulation of the following hypothesis:

H3: Audit Quality is positively related with the tax audit performance

\subsubsection{Commitment}

Commitment is a critical factor to drive the audit responsibility of an auditor to achieve the goals, to protect and preserve the interests of shareholders and stakeholders involved, and to create competitive advantage [8]. Commitment is classified into three different dimensions; "affective, normative and continuance commitment". Staffs who uphold goal orientation are 
more committed to their firms and unions [24]. Research by [30] found that there is a positive relationship on the worker's commitment and loyalty towards goals. This is supported by [43] and a few other studies such as [60] and [58] that showed significant correlation between professional commitment and achieving organizational goals. Case study in Korea indicated significant relationship between age and commitment, as the age increases, so does commitment [70]. Gender and level of education are another personal characteristic that have a relationship with organizational commitment. However, unlike some other studies [79] [13] continuance commitment was found to be positively related to job performance. So, this result contrasted with the argument of some researchers [70] who viewed this concept as a discouraging and negative organizational aspect. Employees may need to develop their performance to guarantee the continuance of their membership, and consequently to benefit from their organizational investments and keep them. The above discussion leads to the formulation of the following hypothesis:

H4: Commitment is positively related with the tax audit performance

\subsubsection{Achievement Orientation}

Achievement orientation is interrelated with commitment. It can be defined as the responsibility of an individual to comply with their duties and accountability towards achieving the conclusive policy direction and implicit goals. The accomplishment of audits vision is appropriate with the recent environment usingmodern technology in practise to assist the continuous enhancement of auditing approach which is suited with current environment [46]. According to [69] [73], the vision is a motivation of an organization to achieve future expectation towards its operation. Proactive vision can foresee the objective job performance of businesses with policies and targets to succeed in the future under the current situation. For auditing perspectives, the auditors have applied proactive vision in order to properly set audit planning and successfully deliver the information and strategy in supporting their outstanding practices for achieving audit success and for auditors' survival. A clear vision and mission is able to create audit responsibility and competency which instils the sense of commitment among the auditors. The above discussion leads to the formulation of the following hypothesis:

H5: Achievement Orientation is positively related with the tax audit performance 


\subsubsection{Skills}

Competencies include both hard and soft skills where it consists of the abilities or proficiencies gained from the previous experiences, such as volunteer work, life events, leisure activities or formal training. Skills are demonstrable, measurable and also transferable from one situation to another [74]. It is agreed that skills and attitude are among the main factors to develop competency. Skills can be divided into interpersonal skills, including communication skills, negotiation skills, listening skills and interviewing skills. Interpersonal skills are among the crucial skills needed by the auditor, especially when facing the resistance of getting co-operation from the taxpayer. The performances of audit work are reflected from cognitive skills and behavioural skills. Emotional intelligence correlates with the attribute such as tolerance to stress, flexibility, listening, managerial skills and sensitivity. Training on fundamental skills is needed for new entrance to be competent in practicing their audit tasks, such as on basic laws and regulation and basic report writing which enables the auditor to draft reports, unsupervised.

On top of that, skills enhancement can also be through sharing session from the existing staffs who are helpful and considered experts in the auditing field. Competency in an auditor can also be obtained by continuously doing auditing. It is also emphasize that tax audit activities will not achieve their objectives without competent staff. An interpersonal skill is one of the important skills required of an auditor. The skills involve the ability to maintain fulfilling relationships between people [53] whether between the clients, teams and other parties. Good interpersonal skills will be able to influence and comfort the interaction with others [81] at the same to time assist the team to achieve their goals. The interpersonal skills consists of problem solving skills, ability to take appropriate technical research, ability to work in a team, skills of evaluating and verifying evidence, communication skills, writing skills and the ability to appropriately treat sensitive and confidential documents. Maintaining good communication can create a positive relationship and avoid any resistance. Therefore, communication skills are really important for a good auditor. Research by [78] found technical skills, analytical skills, appreciative skills, personal and interpersonal skills as important skills required for entry level auditors. According to [75] good communication skills will create effective communication and build a positive rapport between both parties, 
whether with clients or teams, and may create more understanding among human relations. Communication skills not only include oral skills but also written skills, and auditors may benefit from effective communication skills [67]. Listening skill is also one of the communication skills since a good auditor should listen carefully on the justification of an auditee and avoid the defensiveness during audit process. Effective interaction between auditors and auditee is significant to create a successful audit and a good career path, therefore continuous improvement on communication skills is essential for auditors throughout their career. The above discussion leads to the formulation of the following hypothesis:

H6: Skills have significant effect towards tax audit performance

\subsubsection{Team Work}

A dynamic process involving the human interaction in technology and information integration, capabilities and resources [49] Teamwork primary means managing people with various skills and competencies specifically needed for projects or organizations. Hence, the management emphasized the substantial needs on teamwork value may assist with the success of an organization [18]. The management team can easily be constructed or reconstructed, depending on the project needs or requirements [15].

Teamwork is important for continuous improvement and effort on solving problems however it is argued that the team spirit in providing audit quality is limited. Different pool of auditors with various skills and knowledge is required, depending on the requirement of audit task [19]. The key performance indicator of the tax audit officer for 2014 defined the behaviour of individual towards their team in terms of providing support and encouragement towards achieving their goals and objectives, maintain harmony in the team and high team spirit. Teamwork is considered as the spirit of "quality management" and an added value to auditing. A successful auditor must be able to communicate with the team effectively and work together efficiently [41]. The above discussion leads to the formulation of the following hypothesis:

H7: A good teamwork lead to better tax audit performance.

\subsection{Organizational Independence}

There is actually no specific definition on independence in the audit context. However, the 
popular definition in academic is the definition stating that 'the conditional probability of reporting a discovered breach'. Independence can be defined as avoidance of any involvement in any transaction or action which seems to have conflict of interest, including the participation in business with taxpayer, suggesting any professional tax agent to be appointed as tax agent to assist on the audit cases or misuse power in carrying out tasks as stated under 'section 118 of the ITA'. General standard of tax auditors stated that the independence mental attitude is inclusive of strategizing and carrying out audits using 'professional judgement' and staff assigned must be equipped with professional competency to discourse the audit objective, have adequate skills, experience and technical knowledge as well as being well versed with related laws and regulations to be considered as competent personnel's in performing audit work. Only one research stated the relationship between organizational independence and audit performance. Research done by [6] found that organizational independence has positively and significantly affects the audit effectiveness but has negative relation to the outcome. The above discussion leads to the formulation of the following hypothesis:

H8: Organizational Independent is negatively affecting tax audit performance

\subsection{Knowledge and Understanding}

In professional auditing, a broad knowledge of the nature of business and the environment of the industry such as business structure is a non-profit organization, either private or financed, is crucial before an audit began. The knowledge on the industry has significant relationship with the strategy of auditing because auditors can find ways to improve the auditing process [14]. Significant learning of tacit management knowledge occurs between the experienced staff and senior levels. Inexperience auditors with lack of relevant knowledge will limit the auditors' liability to enhance the audit coverage and affect their professional scepticism. For example, junior auditors' have lower technical knowledge and they have to struggle to understand the accounting knowledge and are not able to understand complex accounting treatment, nature of business and other related procedures and accounting terminology. However, inexperience auditors are easier to train [29]. Research by [84] found the significance of knowledge management in producing quality of audit. Deep understanding and knowledge on accounting and nature of business will build the confidence level of an 
auditor, enabling the auditors to perform their roles competently which might affect the audit documentation, audit planning, audit evidence and audit conclusion/ reporting. This is supported by [33] where the level of knowledge in financial reports and tax laws of tax auditors should be in advance level.

Understanding the nature of business is also necessary for an auditor in addition to accounting knowledge. Knowledge is also significant to assist the auditors analyse risk, techniques of control assessment and techniques on risk based audit planning. The above discussion leads to the formulation of the following hypothesis:

H9: Knowledge and understanding is positively influence the tax audit performance

\section{CONCEPTUAL FRAMEWORK OF THE STUDY}

This study is mainly on the competencies factors affecting the capabilities of the tax auditors. Demographic consists of age, gender, education, experiences and number of staffs in audit unit. Whilst, core competencies consists of nine factors: innovation, sustainability, quality, communication, goal orientation, communication skills \& other skills, team work, independence and knowledge. The hypothesis developed from the previous sections has derived the conceptual framework in Fig. 3.

\begin{tabular}{|c|c|}
\hline Categorizing the Independent & Dependent Variable \\
\hline $\begin{array}{l}\quad \text { Core Competency } \\
\text { H1: Innovation } \\
\text { H2: Sustainability } \\
\text { H3: Audit Quality } \\
\text { H4: Commitment } \\
\text { H5: Achievement Orientation } \\
\text { H6: Skills } \\
\text { H7: Team Work } \\
\text { H8: Organizational } \\
\text { Independence } \\
\text { H9: Knowledge\& } \\
\quad \text { Understanding }\end{array}$ & $\begin{array}{l}\text { IRBM Tax } \\
\text { Auditor's } \\
\text { Performance }\end{array}$ \\
\hline
\end{tabular}

Fig.3. Conceptual framework 


\section{DESCRIPTIVE ANALYSIS}

Descriptive analysis was used to analyze the data and the descriptive findings to support objective two of the research; which is to investigate the relationship between core competency factors of the tax auditors and their performance. The objective is to measure the opinion of the tax auditors towards their capabilities through core competencies function in Part C. There are nine factors or elements identified under core competency; namely innovation, sustainability, audit quality, commitment, achievement orientation, skills, teamwork, organizational independence as well as knowledge and understanding. This question required the respondents to rate their perception, the scale used in Part B using Linkert Scale rated from 1 to 5 "Strongly Agree (SA)" to " Strongly Disagree (SD). Results from the descriptive analysis, as shown in Table 2 shows that the mean of every factor under core competency scored slightly the same rating. The overall mean of the nine factors was in between 1.868 to 2.334 and standard deviation was between 0.582 to 0.815 . This indicated that the respondents rated most of the factors as "Strongly Agree(SA)", "Agree(A)" and "Neutral(N)", but mostly rated between 2 to 3 which means "Agree(A)" and "Neutral(N)" since this rating perceived that the majority of auditors' believed that they have enough capabilities in doing audit job and overall rating shows the capabilities as moderate. However, from the survey, respondent number 25 from Kuching branch have rated all the nine factors of core competencies rating 5- "Strongly Disagree (SD)" showing that he perceived that he is not competent in doing his job. Further analysis on the questionnaire answered by the respondent identified that the respondent felt demotivated and suggested the management not to underestimate the capabilities of the staff and there was no proper place to perform audit task. From the nine elements, the respondents rated the organizational independence and goal orientation as highest competency with the mean of 1.868 and 1.899 and standard deviation of 0.815 and 0.781 respectively. The result showed that the respondents understood their Key Performance Indicator (KPI) well and were confident that they are able to achieve the IRBM goals and excel in their job. In addition to that, the auditors believed they always uphold the independence of an auditor which is the critical part of being an auditor, they also understand that there should not be any business with clients who are exposed to conflict of interest which may affect the professional judgement of an auditor towards its audit opinion. Other 
factors is rated slightly the same which showed that auditors' have moderate competency in terms of innovation and auditors perceived they are innovative enough to benefit the department by generating wise ideas to enhance audit procedures, way of thinking and increase the effectiveness of audit work. All the nine variables were interrelated in generating effectiveness of audit work and competency among auditors in the auditing field.

Table 2. Descriptive analysis on the perception of core competency factors

\begin{tabular}{llll}
\hline Factors & Mean & Standard Deviation & Range \\
\hline Innovation & 2.275 & 0.582 & $2.18-2.46$ \\
\hline Sustainability & 2.309 & 0.587 & $2.07-2.45$ \\
\hline Audit Quality & 2.234 & 0.645 & $2.02-2.44$ \\
\hline Communication & 2.136 & 0.655 & $1.98-2.28$ \\
\hline Goal Orientation & 1.899 & 0.781 & $1.84-1.94$ \\
\hline Skills & 2.334 & 0.619 & $2.13-2.73$ \\
\hline Team Work & 2.143 & 0.751 & $2.09-2.18$ \\
\hline Organizational Independence & 1.868 & 0.815 & $1.85-1.89$ \\
\hline Knowledge \& understanding & 2.243 & 0.679 & $2.00-2.35$ \\
\hline Total & & & \\
\hline
\end{tabular}

\section{LOGISTICS REGRESSION}

To achieve the objective; an investigation was conducted on the relationship between core competencies factors and the tax auditors performance. In this analysis, the Independent Variables (IV) is core competency factors which consist of innovation, sustainability, audit quality, communication, goal orientation, skills, team work, organizational independence and knowledge \& understanding. The independent variables have been regressed towards the dependent variable (DV):- (which reflected question 8 in part B); the duration of a tax audit officer to complete one audit case (less than 2 months). The results of the logistic regression analysis are as per Table 3. 
Table 3. Logistic regression predicting likelihood of the core competency contribution towards their performance

\begin{tabular}{lcccccc}
\hline & B & S.E. & Wald & df & Sig. & Exp(B) \\
\hline Innovation & 0.766 & 0.69 & 1.231 & 1 & 0.267 & 2.151 \\
Sustainability & -0.764 & 0.912 & 0.702 & 1 & 0.402 & 0.466 \\
Audit Quality & 0.066 & 0.695 & 0.009 & 1 & 0.924 & 1.068 \\
Commitment & -0.406 & 0.799 & 0.258 & 1 & 0.611 & 0.666 \\
Achievement orientation & -0.047 & 0.55 & 0.007 & 1 & 0.932 & 0.954 \\
Skills & 1.097 & 0.553 & 3.941 & 1 & $0.047^{*}$ & 2.996 \\
Teamworks & -0.096 & 0.579 & 0.028 & 1 & 0.868 & 0.908 \\
Organizational Independence & -0.02 & 0.463 & 0.002 & 1 & 0.965 & 0.98 \\
Knowledge \& understanding & 1.108 & 0.551 & 4.046 & 1 & $0.044^{*}$ & 3.028 \\
2 Log-likelihood & 142.53 & & & & & \\
Model Chi-Square & 8.401 & & & & & \\
\hline
\end{tabular}

* Sig. level $<0.05$

The statistical analysis result shows that out of the nine variables only two variables significantly affect the tax auditor's performance. The variables are skills as well as knowledge and understanding with the significant level of 0.047 and 0.044 respectively. Although other variables do not seem significant, the significant level however, is below than 1 which was still needed by a tax auditor to perform their task. Part of the nature of being an auditor is to have the main element, which is understanding and knowledge on the nature of business and related tax laws, as well as skills. Therefore, the hypothesis for skills and knowledge and understanding are supported.

If the tax auditors did not have understanding and knowledge on the tax regulation and do not understand the nature of business and are not well versed in accounting treatment, it is difficult for tax auditors to detect gaps in the tax reported to IRBM. This finding is also consistent with the research done by [42] who found that more than $30 \%$ of respondents argued that tax auditors provide inconsistent comment and non- compliance to tax and regulation due to lack of knowledge. Apart from that, the research also found that tax auditors took long duration to finalize their audit cases. Moreover, due to lack of knowledge on the nature of business and accounting treatment, the tax auditors will not be able to justify the tax adjustment produced for the cases and required additional payment. This issue is consistent 
with the finding of research done by [42] and [17]. The result showed that most of the time the tax auditors generalized the modus operandi of business transaction in the same nature of business or industry although sometimes the modus operandi differ from one company to another.They also did not agree with the justification given by the taxpayer and make the tax adjustment based on their judgment which sometimes fail to provide justification on the tax adjustment and required additional tax payment upfront. This might also be due to lack of knowledge on accounting treatment which needs to be updated overtime. This issue is consistent with [33] stating the deep understanding and knowledge on accounting and nature of business is essential to enable the auditors to perform their role competently which might affect the audit documentation, audit planning, audit evidence and audit conclusion or reporting. Furthermore, the level of knowledge of an auditor in financial report and tax laws should be in an advance level to uphold the professionalism and respect deserved towards the tax administrator. According to this survey, the respondents mostly have within 1- 3 years' experience in Audit Unit IRBM which can be considered as less experienced. Inexperienced auditors with lack of relevant knowledge will limit their ability to extend the audit coverage and affect their professional scepticism. For example, junior auditors have lower technical knowledge and they have to struggle to understand the accounting details and are not able to understand complex accounting treatment, nature of business and other related procedure and accounting terminology.

However, it is believed that all the auditors have enough technical knowledge in terms of tax regulation. This is because IRBM has provided a training plan for audit staff every year to enhance their technical knowledge in terms of tax laws and regulation. Every year, the tax officers will be sent for training and they have to attend basic and advance tax courses to ensure they have been updated with tax laws and regulation. The IRBM's Annual Report 2004 also listed a total of 136 sessions of courses to be attended by the tax officers [40] [71].Tax auditors' work closely with clients as a team, therefore, having appropriate skills is crucial to an auditor. Knowledge, without skills, will not help a tax auditor to use their knowledge appropriately. Basically, these skills can be divided into interpersonal skills, including communication, negotiation, listening and interviewing skills. Interpersonal skills is able to develop critical thinking to assist the tax auditors to find discrepancies in the financial 
accounts and also solution to face the taxpayer's resistance in giving cooperation. Good interpersonal skills will help to influence others to feel comfortable and can easily give co-operation and indirectly assist the tax auditors to resolve complicated cases and reduce the number of unresolved cases. In addition, if the auditor is well equipped with the core competency, such as skills and being innovative, the unresolved cases could be settled and there will be no issues on receiving insufficient co-operation from the taxpayer. Interpersonal skills are significant for an auditor to communicate with the taxpayer to obtain the documents besides having critical thinking and being innovative in handling complex cases. It is argued by [42] who found $70 \%$ of the respondent felt the pressure during audit fieldwork while the respondent also disclosed tax audit officer showed rude attitude to the auditee and also raised their voices during audit fieldwork.

Although other independent variables seemed to be insignificant to measure the tax auditors' performance, the survey was based on the sample of tax auditors' opinion on their performance where their opinion might not meet the actual performance. From the survey, the auditors might be satisfied with their audit work because more than $90 \%$ of the respondent achieved their annual KPI although they have many unresolved tax audit cases pending. This showed that the tax auditor focus on quantitative rather than qualitative of the audit conducted.

\section{CONCLUSION}

The objective of this research is to investigate the relationship between core - competency factors of the tax auditors and their performances. The result of the analysis shows that knowledge and understanding as well as skills had significantly influenced the tax auditors' performance.

The worldwide challenge faced by auditors around the world is the competencies such as technical knowledge, skills and also attitudes. The professional knowledge and skills cannot be gained from a university education. In a nutshell, auditors work based on facts. As a tax auditor, it is important for an auditor to be well versed in tax terminology as well as tax laws and regulation for them to verify the tax reported to IRBM. Apart from that, it is important for a tax auditor to master the accounting treatment and understand the accounting term as well as 
be updated with the latest accounting news for them to read the financial report and verify the gap of the financial report in ensuring the income reported is true. Lack of basic accounting knowledge will affect the tax auditor from understanding the basic journal entries or reconciliations. Subsequently, the tax auditors will not understand the accounting treatment and the accounting terminology. Moreover, the knowledge and understanding is also vital for a tax auditor to understand the nature of business because sometimes the company audited do not have proper records of their account. Therefore, the auditor has to use their creativity in order to get the information on to gain income.Inadequate knowledge in term of tax law, accounting treatment and nature of business may cause delay in finalizing the audit case and prolong the audit duration. This is supported by [42] who found $30 \%$ of respondents argued that tax auditors provide inconsistent comment and non- compliance to tax and regulation due to lack of knowledge and tax auditors took a long time to finalize the audit cases. On top of that, lack of knowledge in terms of the nature of business will encourage the tax audit officers to generalize the modus operandi of business transaction in the same nature of business or industry, although sometimes the modus operandi differ from one company to another. Sometimes the tax auditor fails to provide justification on the tax adjustment and required additional tax payment upfront.

Communication skills is also one of the important skills needed by the tax auditor and who found that communication skills are required to ensure the ability of a tax audit officer to communicate well and share or exchange information and ideas without difficulty. Effective communication is an important equipment for a successful auditor. Apart from that, the analytical or intellectual skills as competencies is also important [51] especially to assist the auditor analyse or use logical reasoning in a satisfactory way, thus exhibiting the faculty of reasoning and understanding. Additionally, the analytical or critical thinking skills is demanding for more innovative problem solvers and critical thinkers who will focus on problem identification and problem solving since the interpersonal skills is a necessity for an auditor as they work directly with people and it involves the ability to maintain fulfilling relationships between people. 


\section{REFERENCE}

[1] Abdul-Jabbar H, Pope J. The effects of the self-assessment system on the tax compliance costs of small and medium enterprises in Malaysia. Australian Tax Forum, 2008, 23, 89-307.

[2] Ahmad N, Mohammed Z M, Iskandar T M, Hanefah H M M, Faizal S M. Outsourcing Malaysia federal tax audit: The stakeholders' views. Jurnal Pengurusan, 2014, 41, 13-24.

[3] American Institute of Certified Public Accountants. Annual report accounting education centre: Personal competencies, 2005.

[4] Alleyne P, Howard M. An exploratory study of auditors' responsibility for fraud detection in Barbados. Managerial Auditing Journal, 2005, 20(3): 284-303

[5] Arens A, Elder R, and Beasley M. Auditing and assurance services: An integrated approach (9th ed.) Englewood Cliffs: Prentice-Hall, 2003

[6] Ayalew E. Factors Affecting tax audit effectiveness: A study on category 'A' Taxpayers in Bahir Dar City Administration Revenue Office. Unpublished Thesis, Masters of Science in Accounting and Finance, Bahir Dar University, 2014

[7] Baradihi F. An exploratory case study on the influence of sustainability on employee engagement. Unpublished Thesis, Doctor of Business Administration, Lawrence Technological University, 2012

[8] Barker V L, Mueller G C. CEO characteristic and firm R\&D spending. Management Science, 2002, 48(1): 782-801

[9] Birchall D, Chanaron J J, Tovstiga G, and Hillenbrand C. Innovation performance measurement: Current practices, issues and management challenges. International Journal of Technology Management, 2011, 56(1): 1-20.

[10] Blokdijk J H. Tests of control in the audit risk model: Effective or efficient? International Journal of Auditing, 2004, 8(2): 185-194.

[11] Braithwaite V. Responsive regulation and taxation: Introduction. Law \& Policy, 2007, 29(1): 3-10

[12] Brocheler V, Steven M, and Witteloostuijn van, A. Auditor, human capital and audit survival: The Dutch audit industry in 1930-1992. Accounting, Organizations and Society, 2004, 29(7): 627-646

[13] Caruana A. Ewing M, and Ramaseshan B. Organizational commitment and performance: 
The Australian public sector experience. School Research Series, 1997

[14] Chaganti R, Sambharya R. Strategic orientation and characteristics of upper management. Strategic Management Journal, 1987, 8(4): 393-401.

[15] Chang T J, Hu G G, and White L P. The effectiveness model of cross-functional project teams in Taiwan. Proceedings of the 12th International Conference on Comparative Management, 2000.

[16] Chanruang S, Ussahawanitchakit P. Audit Sustainability of CPAs in Thailand: Effects of audit planning competency and audit report quality. International Journal of Business Research, 2011, 11(6): 55-82

[17] Choong K F, Lai M L. Tax practitioners' perception on tax audit and tax evasion: Survey evidence in Malaysia. International Business Research Conference, 2008

[18] Cohen S G, Bailey D E. What makes teams work: Group effectiveness research from the shop floor to the executive suite. Journal of Management, 1997, 23(3): 239-290

[19] Dodin A, Elimam, A, Rolland E. Tabu search in audit scheduling. European Journal of Operational Research, 1998, 106(2-3): 373-392

[20] Eilifsen A. Auditing regulation and the statutory auditor's responsibilities in Norway. The European Accounting Review, 1998, 7(4): 709-722.

[21] Essman H E. Toward innovation capability maturity. Unpublished Thesis, Doctor of Philosophy, Stellenbosch University, South Africa, 2009

[22] Fatt C K, Ling L M. Tax practitioners' perception on tax audit and tax evasion: Survey evidence in Malaysia. $8^{\text {th }}$ International Business Research Conference, 2008

[23] Fearnley S, Beattie V, and Brandt R. Auditor independence and audit risk: A conceptualisation. Journal of International Accounting Research, 2005, 4(1): 39-71

[24] Fields M, Thacker, J. Influence of quality of work life on company and union commitment. Academic Management Journal, 1992, 35(2): 439-450

[25] Flavian C, Tores E, and Guilaniu M. The influence of corporate image on consumer trust: A comparative analysis in traditional versus internet banking. Internet Research, 2005, 15(4): 447-470.

[26] Fogarty T J. Public accounting work experience: The influence of demoghraphic and organizational attributes. Managerial Auditing Journal, 1994, 9(7): 12-20 
[27] Frey B S. Deterrence and morale in Taxation in the European Union. European Review, 2003, 11(3): 385-406

[28] Ghani N A M Y, Ling L M, and Wah Y B. Tax noncompliance among small and medium-enterprises in Malaysia: Tax audit evidence, The Business School, 2012, 1-23

[29] Glover P S M, Prawitt D F. Enhancing auditor professional scepticism. Brigham Young Universiti, 2013, 1-23

[30] Gnanayudam J, Dharmasiri A. The influence of quality of work-life on organizational commitment: A study of the apparel industry. Sri Lankan Journal of Management, 2008, 13(12): $117-140$

[31] Hai D O T, See L M. Behavioral intention of tax non-compliance among sole-proprietors in Malaysia. International Journal of Business and Social Science, 2011, 2(6): 142-152

[32] Holm C, Zaman M. Regulating audit quality: Restoring trust and legitimacy. Accounting Forum, 2012, 36(1): 51-61

[33] International Federation of Accountants. Code of ethics for professional accountants, 2005

[34] International Federation of Accountants. Handbook of international auditing, assurance and ethics pronouncements, 2006

[35] International Auditing and Assurance Standard Board. A framework for audit quality, 2013

[36] Inland Revenues Board Malaysia. IRBM Annual Report, 2009

[37] Inland Revenues Board Malaysia. IRBM Annual Report, 2010

[38] Inland Revenues Board Malaysia. IRBM Annual Report, 2012

[39] Inland Revenues Board Malaysia. IRBM Annual Report, 2013

[40] Inland Revenues Board Malaysia. IRBM Annual Report, 2014

[41] Inland Revenues Board Malaysia. Key Performance Indicator (KPI), 2014

[42] Isa K, Pope J. Corporate tax audits: Evidence from Malaysia. Global Review of Accounting and Finance, 2011, 2(1): 42-56

[43] Jackson S E. Consequences of group composition for the interpersonal dynamics of strategic issues processing. Advances in Strategic Management, 1992, 8, 345-382

[44] James A B. Core competency for todays international auditor. The institute of Internal 
Auditors, 2010

[45] Craig J T. Antecedents of individual innovative behavior: Examining transformational leadership, creative climate, role ambiguity, risk propensity, and psychological empowerment. Unpublished Thesis, Doctor of Philosophy, Alliant International University, 2015

[46] Johnson G, Scholes K. Exploring corporate strategy. Harlow, England: Prentice Hall, 1999

[47] Smith K W. Reciprocity and fairness: Positive incentives for tax compliance. Chicago: American Bar Foundation, 1992

[48] Kim T Y, Hon A H Y, and Crant J M. Proactive personality, employee creativity, and newcomer outcomes: A longitudinal study. Journal of Business and Psychology, 2009, 24(1): 93-103

[49] Kinlaw D C. Developing superior work teams. San Diego, California, USA: Lexington Books, 1991

[50] Kirchler E. Balance between giving and receiving: Tax morality and satisfaction with fiscal policy as they relate to perceived just distribution of public resurces. Reitaku International Journal of Economic Studies, 1997, 5, 59-70

[51] Lange P, Jackling B, and Gut A. Accounting graduates' perceptions of skills emphasis in undergraduate courses: An investigation from two Victorian universities. Accounting and Finance, 2006, 46(3): 365-386

[52] Lin J W, Hwang M I. Audit quality, corporate governance, and earnings management: A Meta-Analysis. International Journal of Auditing, 2010, 14(1): 57-77

[53] Little W, Fowler H W, and Coulson J. The shorter Oxford English dictionary on historical principles, Oxford: Clarendon Press, 1973

[54] Ma J, Ma C. Factor analysis based on the COSO framework and the government audit performance of control theory. Procedia Engineering, 2011, 15, 5584-5589

[55] Mahmud M. Compliance risk management strategies for tax administrations in developing countries: A case study of the Malaysian revenue authority. Unpublished Thesis, Doctor of Philosophy, University of Warwick, 2012

[56] Makkawi B, Schick A. Are auditors sensitive enough to fraud? Managerial Auditing Journal, 2003, 6(18): 591-598 
[57] Mano R M, Mouritsen M L, and James G S. Accounting Profession, heal theyself: A matter of survival. The CPA Journal, 2003, 73(8): 6-9.

[58] Mathieu J, Zajac D. A review of meta-analysis of the antecedents, correlates and consequences of organizational commitment. Psychological Bulletin, 1990, 108(2): 171-194

[59] McManus J. Enhancing tax auditors' capability: Tackling non-compliance head on. Birmingham: Fiscal Publication, 2006

[60] Meyer J, Allen N. Testing the "side- bet theory" of organizational commitment: Some methodological considerations. Journal of Applied Psychology, 1984, 69(3): 372-378

[61] Newman D P, Patterson E R, and Smith J R. The role of auditing in investor protection. The Accounting Review, 2005, 80(1): 289-313

[62] Ng T W H, Feldman D C. Age and innovation-related behavior: The joint moderating effects of supervisor undermining and proactive personality. Journal of Organizational Behavior, 2013, 34(5): 583-606

[63] Nicolaou I A. A contingency model of perceived effectiveness in accounting information systems: Organizational coordination and control effects. International Journal of Accounting Information Systems, 2000, 1(2): 91-105

[64] Palil M R. Tax knowledge and tax compliance determinants in self assessment system in Malaysia. Unpublished Thesis, Doctor of philosophy, The University of Birmingham, 2010 [65] Palil M R, Mustapha A F. The evolution and concept of tax compliance in Asia and Europe. Australian Journal of Basic and Applied Sciences, 2011, 5(11): 557-563

[66] International Forum of Independent Audit Regulators. Report on 2016 survey of inspection findings, 2016

[67] Smith, G. Communication skills are critical for internal auditors. Managerial Accounting Journal, 2005, 20(5): 513-519

[68] Prahald C K, Hamel G. The core competency of the corporation. Harvard Business Review, 1990

[69] Price W H. Vision and change: The relationship between vision and change in organization. Unpublished Thesis, Doctor of Philosophy, Southeastern University, 2001 [70] Randall D M, O'Driscoll M P. Affective versus calculative commitment: Human resource implications. The Journal of Social Psychology, 1997, 137(5): 606-617 
[71] Inland Revenue Board Malaysia. Annual Report, 2004

[72] Röglinger M, Pöppelbuss J, and Becker J. Maturity models in business process management. Business Process Management, 2012, 18(2): 328-346

[73] Salem M S M. An overview of research on auditor's responsibility to detect fraud on financial statements. Journal of Global Business Management, 2012, 8(2): 218-229

[74] Saskatchewan Public Service Comission. In scope competency profiles, 2007

[75] Sawyer L B, Dittenhofer M A, and Scheiner J H. Sawyer's internal auditing: the practice of modern internal auditing $\left(5^{\text {th }}\right.$ Ed.). Altamonte Springs, Florida: The Institute of Internal Auditors, 2003

[76] Schleifer L L F, Greenawalt M B. The internal auditor and the critical thinking process. Managerial Auditing Journal, 1996, 11(5): 5-13

[77] Seibert S E, Crant J M, and Kraimer M L. Proactive personality and career success. Journal of Applied Psychology, 1999, 84(3): 416-427

[78] Seol I, Sarkis J, and Lefley F. Factor structure of the competency framework for internal auditing (CFIA) skills for entering level internal auditors. International Journal of Auditing, 2011, 15(3): 217-230

[79] Sethivikram V, Meinert D, Kingrking R, and Sethiavsethi V. The multi-dimensional nature of organizational commitment among information systems personnel. Second Americas Conference on Information Systems, 1996

[80] Shippmann J S, Ash R A, Batjtsta M, Carr L, Eyde L D, Hesketh B . . Sanchez J I. The practice of competency modeling. Personnel Psychology, 2006, 53(3): 703-740

[81] Siegel G. Changing work roles demand new knowledge and skills. Strategic Finance, 2000, 81(8): 65-66

[82] Solomon S, Philip M J R, and Jordan L J. The impact of management image and non-audit service fees on investors' perceptions of earnings quality. Advances in Accounting, 2005, 21, 199-216.

[83] Kira A R. An evaluation of goverments' initiatives in enhancing small taxpayers' voluntary tax compliance in developing countries. International Journal of Academic Research in Accounting, Finance and Management Sciences, 2017, 7(1): 253-267

[84] Wangraj P, Ussahawanitchakit P, and Muenthaisong K. Audit responsibility competency 
and audit survival: Evidence from tax auditors (TAs) in Thailand. AU-GSB e-Journal, 2014, 7(2): 2-25.

[85] West M A, Hirst H, Richter A, Shipton H. Twelve steps to heaven: Successfully managing change throught developing innovative teams. European Journal of Work and Organizational Psychology, 2004, 13(2): 269- - 299

[86] Williamson M R, Wearing A J. Lay people's cognitive models of the economy. Journal of Economic Psychology, 1996, 17(1): 3-38

[87] Inland Revenue Department. Inland Revenue Department Staff Training Procedure, 1982

[88] Inland Revenue Board Malaysia. Tax Operation Department Malaysia, 2015

[89] Berita Nasional Malaysia. Audit akan libatkan semua pembayar cukai pada masa akan datang, kata LHDN, 2016

[90] Michigan Government. Tax compliance bureau audit standards. 2013, 606-617

[91] The Institute of Internal Auditors Research Foundation. Internal audit capability model (IA-CM): For the public sector, 2009

\section{How to cite this article:}

Nadiah A H, Siti Hajar A M, Zarinah A R. The influence of core competency skills of irbm tax auditors towards their performance. J. Fundam. Appl. Sci., 2017, 9(5S), 958-988. 